\title{
CITIZENS' RIGHTS AND ADMINISTRATION DUTIES IN ENVIRONMENTAL MATTERS: 20 YEARS OF THE AARHUS CONVENTION
}

\section{DERECHOS DE LOS CIUDADANOS Y DEBERES DE LA ADMINISTRACIÓN EN MATERIA DE MEDIO AMBIENTE: 20 AÑOS DEL CONVENIO DE AARHUS}

\author{
LUDWIG KRÄMER
}

Received: April 23rd, 2018 / Accepted: June $20^{\text {th }}, 2018$

\begin{abstract}
The article takes advantage of the 20th anniversary of the Aarhus Convention (25 June 2018) to trace how it has developed. For the three pillars of the Convention - access to information, public participation in decision-making and access to justice in environmental matters - it describes and assesses its main impacts on the situation of the European Contracting Parties, and points to the weaknesses in its practical application. Overall, it strikes a positive balance of the effects of the Convention, though it points out that significant improvements are still necessary.
\end{abstract}

Resum: Aquest article aprofita el vintè aniversari del Conveni d'Aarhus (25 de juny de 2018) per descriure com ha evolucionat al llarg dels últims vint anys. Per a cada un dels tres pilars -accés a la informació, participació pública en el procés de presa de decisions i dret a l'accés a la justícia- descriu i valora els impactes principals del Conveni sobre la situació de les parts contractants europees, i detalla els punts febles de la seva aplicació pràctica. En conjunt, fa una valoració positiva dels efectes del Conveni, però destaca que encara cal fer-hi millores significatives.

Resumen: Este artículo aprovecha el vigésimo aniversario del Convenio de Aarhus (25 de junio de 2018) para describir su evolución a lo largo de estos años. Para cada uno de los tres pilares - acceso a la información, participación pública en el proceso de toma de decisiones y derecho al acceso a la justicia- describe y valora sus principales impactos en la situación de las partes contratantes europeas, y detalla los 
puntos débiles de su aplicación práctica. En conjunto, hace una valoración positiva de los efectos del Convenio, pero subraya que aún deben introducirse mejoras significativas.

Keywords: Environment - Aarhus Convention - right to information, right to participation in decision-making - right of access to justice - EU law

Paraules clau: Medi ambient - Conveni d'Aarhus - dret a la informació - dret a participar en la presa de decisons - dret d'accès a la justícia - dret comunitari

Palabras clave: Medio ambiente - Convenio de Aarhus - derecho a la información derecho a participar en la toma de decisiones - derecho de acceso a la justicia derecho comunitario

Summary: I. Access to information on the environment. II. Public participation in environmental decision-making. III. Access to environmental justice. IV. A balance.

The Aarhus Convention ${ }^{1}$ was signed in Aarhus (Denmark) on 25 June 1998. Since then it has been ratified by 46 States and the European Union and entered into force in 2001. A Protocol on Pollutant Release and Transfer Registers was ratified by 36 Parties, including the European Union (EU) and its Member States, and entered into force in 2009. An amendment of the Convention to provide for public participation in decisions on the release of genetically modified organisms has not yet entered into force, but was ratified by the EU and its Member States. ${ }^{2}$ The United States, Canada and Russia took part in the negotiations on the Convention, but did not sign it.

The Convention states its objective as follows: "In order to contribute to the protection of the right of every person of present and future generations to live in an environment adequate to his or her health and well-being, each Party shall guarantee the rights of access to information, public participation in decision-making and access to justice in environmental matters in accordance with the provisions of this Convention" (Article 1). The following articles 2 to 10 elaborate on these three pillars; the remaining articles 11 to 22 contain procedural aspects of the Convention, such as the right to vote, amendments to the Convention or the settlement of disputes. Article 13 is of some

1 Convention on access to justice, public participation in decision-making and access to justice in environmental matters.

2 www.unece.org/env/pp/ratification.html (3April 2018) 
importance because it provides for a non-confrontational, non-judicial and consultative mechanism to review compliance with the provisions of the Convention.

This was the first time that an international convention formulated rights for citizens regarding access to environmental information, their right to participate in decisions which affect the environment and their right of access to justice in environmental matters. ${ }^{3}$ Such rights had never before been formulated in such explicit terms in any of the legislation of the Contracting Parties or the European Union. While there were rules on access to information ${ }^{4}$ and rudimentary provisions on public participation in decision-making ${ }^{5}$ in the European Union and, hence, in its Member States, the provisions of the Convention covered entirely new ground for the countries in Central and Eastern Europe, and Asia which had been under the dominance of the Soviet Union until the Berlin wall came down. The fact that citizens could enforce their rights against the public authorities in court was innovative for these countries. It was innovative that, for the first time, environmental protection was more than just lip service and was suddenly being taken seriously. It was even said to be of general interest.

The text below will not retrace the negotiations which led to the conclusions of the Aarhus Convention, as there is already sufficient literature on this subject. Rather, it will try to assess the impact of the three "pillars" of the Convention - access to information, participation and access to justice - on the Contracting Parties. In view of the important role of the EU - 28 of the 46 Contracting Parties are EU Member States - and after a short general introduction, for each of the three pillars the achievements and omissions will be presented for the EU itself , the EU Member States and the other Contracting Parties. However, a detailed analysis of the impact of the Aarhus Convention on each of the 47 Contracting Parties would exceed the space of this paper.

The United Nations Economic Commission for Europe (UNECE), under whose authority the Aarhus Convention was negotiated and concluded, issued a guide on the interpretation of the Convention which was drafted by a number of independent

\footnotetext{
${ }^{3}$ The Rio Declaration on Environment and Development of 1992 contained a Principle X which also referred to the three aspects mentioned above. However, this Declaration formulated non-binding principles only.

${ }_{4}^{4}$ Directive 90/313 on the freedom of access to information on the environment, OJ 1990, L 156 p.58.

5 Directive 85/337 on the assessment of the effects of certain public and private projects on the environment, OJ 1985, L 175 p.40, articles 6 and 7. This Directive has since been replaced by Directive 2011/92, OJ 2012, L 26 p.1.
} 
lawyers. ${ }^{6}$ For this reason, the guide is not the official interpretation, though it is helpful for understanding and interpreting the various provisions of the Convention.

There is no single court entrusted with the interpretation of the Convention in the territory of the Convention; the International Court of Justice which could be asked to give a judgment in the case of a dispute between two Contracting Parties ${ }^{7}$ has yet to be appealed to. The European Court of Human Rights is competent to decide on possible infringements of the European Convention on Human Rights and Fundamental Freedoms. Nevertheless, this Convention neither contains an individual right to a clean environment nor directly refers to the three procedural rights of the Aarhus Convention.

The Court of Justice of the EU (CJEU) is only competent to discuss EU law. As the EU ratified the Aarhus Convention, its provisions are part of EU law, so the CJEU is competent to interpret them. ${ }^{8}$ Although this interpretation only applies to the $28 \mathrm{EU}$ Member States, de facto the CJEU judgments also influence the interpretation of the Aarhus Convention in non-EU countries.

The Aarhus Convention Compliance Committee was set up under Article 13 of the Convention. It is entitled to receive and assess "communications" - de facto complaints - from members of the public. ${ }^{9}$ By the end of March 2018, 157 complaints had been received, plus two complaints from one State against another. ${ }^{10}$

The findings of the Compliance Committee need to be approved by the Meeting of the Parties to the Convention (MEP) in order to be legally effective. Until March 2018, all findings had been approved by the MEP. ${ }^{11}$ In practice, these findings have a widespread echo and have effects similar to those of a court judgment.

6 Ebbesson, J., Gaugitsch, H., Jendroska, J., Stec, S. Marshall, F.: The Aarhus Convention. An implementation guide. 2nd ed. Geneva 2014.

7 See Article 16 of the Convention.

${ }^{8}$ Court of Justice of the EU (CJEU), caseC-240/09, Lesoochranárske zoskupenie, ECLI:EU:C:2011:125, paragraph 30: "the provisions of that Convention [Aarhus Convention] now form an integral part of the legal order of the European Union"; paragraph 32: "The Court has jurisdiction to define the obligations which the Community has assumed."

${ }^{9}$ See Andrusevich, A., Kern, S: Case law of the Aarhus Convention Compliance Committee 2004-2014. 3rd ed. Lviv 2016.

10 See https://www.unece.org/env/pp/cc.html (assessed 3 April 2018).

11 See, however, case ACCC/C/32 part II (n.10, above); the meeting of the Parties decided in 2017 to postpone a decision on the findings of the Compliance Committee against the EU until its next meeting (2021), as decisions by the Meeting of the Parties are normally taken unanimously and the EU heavily opposed the findings of the Compliance Committee. 
Every three years, the Contracting Parties to the Convention send reports to the Aarhus Convention Secretariat, in which they inform on the implementation and application of the Convention's provisions. ${ }^{12}$ These reports provide useful information on the legislative, and sometimes also the administrative, measures that have been taken. However, as the reports are produced by the central Government, they do not normally contain omissions, erroneous applications, systematic disregard for provisions of the Convention or other problems regarding the effective application of the Convention. Although the Aarhus Convention requires transparency and participation, national reports are only very exceptionally submitted, before dispatch, to consultation, so that the public or environmental organizations can be allowed to comment. $^{13}$

The Convention secretariat also publishes reports from environmental organizations or other bodies on the state of implementation in their countries. ${ }^{14}$ These reports give a wealth of factual and legal information on the application of the Aarhus Convention, which often directly contradicts the official national report. To give just one example, the national reports almost never mention the problem of administrative silence on applications for information on the environment; for the NGOs, this is one of the main drawbacks of the application of the Convention.

\section{Access to information on the environment}

The first pillar of the Aarhus Convention - access to environmental information - is fundamental for the whole of the Convention. For this reason, the Preamble to the Convention insists on the need for accountability and transparency, and expresses the opinion that the implementation of the Convention "will contribute to strengthen democracy", a statement that gained its full weight in the countries of Central and Eastern Europe and Asia which became fully independent after 1990.

The Convention grants an individual human right of access to information on the environment that is held by public authorities. ${ }^{15}$ It does not extend to information held

\footnotetext{
12 The reports are made available under https: www.unece.org/env/pp/reports.html (assessed 3 April 2017). There are reports for the years 2005, 2008, 2011, 2014 and 2017.

13 One such exception is the German report 2017. Germany also published the comments of the NGOs in the draft national report.

14 https://www.unece.org/env/pp/reports_organisations_2017.html (assessed 6 April 2017). NGOreports are available on Croatia, Austria, Hungary, Bosnia-Herzegovina, Kazakhstan, Belarus and Czechia.

15 The human right-character of the rights is illustrated by the fact that the rights are available to the general public everywhere, independently of nationality, residence or domicile (see Article 3(9) of the Convention).
} 
by private persons or companies. However, it gives a very wide-ranging definition of "public authorities" (Article 2 no. 2): every person or body which has or exercises powers that are not available to individual citizens, is considered to be a public authority. Thus, for example, a university, or a water management body, a chamber of agriculture, industry or commerce, or a government-appointed committee of experts, must be regarded as public authorities. And there is no need for the public authority to work in the area of environmental policy. Authorities working in transport, energy, agriculture, fisheries or tourism may also have information about the environment.

Recital 17 of the Convention states that "public authorities hold environmental information in the public interest." This is key to understanding the meaning and importance of the first pillar. Public authorities have a tendency to act according to the slogan that knowledge gives power. Thus, in their eyes, sharing knowledge means sharing power, and authorities often do not acknowledge in practice that they hold information on the environment not in their own or their superiors' interest, but in the public's. Therefore, they often disclose environmental information not spontaneously but on request, and not on omissions or failures but on success stories. And they try to delay the disclosure of information when an earlier disclosure might cause concern for the general public or influence public debate in one way or another (for example, for or against a particular infrastructure project).

The Convention dedicated a full Article (Article 5) to the active dissemination of information which, because of technological advances, has now become much easier. The main aim of the Convention is to set up publicly accessible lists, registers or files, where environmental information is stored. Citizens may then request access to this or that document and information can be disclosed, unless one of the exceptions mentioned in Article 4 of the Convention applies. In order to be operational these registers should be available at municipal, regional and national level and be carefully structured, so that the general public can readily find the information they are looking for. Current practice in almost all countries - perhaps with the exception of Sweden is a long way from this ideal situation.

Following a EU directive on access to information which was addressed to EU Member States, the EU progressively adopted provisions on access to documents held by the 
European Parliament, the Council and the Commission. ${ }^{16}$ Following the ratification of the Aarhus Convention in 2005, ${ }^{17}$ it adopted provisions on the access to environmental information and extended the right of access to all documents held by an EU institution or body. ${ }^{18}$

Overall, transparency at the EU level has considerably increased since the adoption of the Aarhus Convention in 1998, with the provisions on access to environmental information being a frontrunner. The European Environment Agency, which was set up in 1990, played a prominent role in the collection, processing and distribution of environmental information, although information on environment-related agricultural and fishery problems, transport and energy, competition, trade and socio-economic factors remains scarce. The absence of a European public opinion neither facilitated access to environmental information in the above-mentioned areas nor did it lead to a systematic dissemination of environmental information by the EU authorities. In particular, the EU Commission's register of documents is grossly insufficient, as it lists only those documents which reached the Commission executive itself. All documents that remained at the level of the Commission directorates-general (studies, statistical data, lobbyists' representations etc.) are not registered, so they are difficult to access because they must be known to exist and this is easier for large vested interests than for citizens.

Another area in which transparency can be improved is the decision-making process. The Commission publishes its decisions on legislative options only after deciding in favor of one option. The so-called comitology-procedure and the trilogue procedure for regulatory and legislative decisions remain largely confidential, in particular as regards the voting behavior of the EU Member States.

The Convention allows for the non-disclosure of commercial and industrial information, "where such confidentiality is protected by law in order to protect a legitimate economic interest", although this excludes emissions into the environment (Article 4 (4.d)). This exception must be interpreted in a restrictive way that takes into account the public's interest in disclosure (Article 4(4), last subparagraph). Several EU Regulations provide

\footnotetext{
${ }^{16}$ Regulation 1049/2001 regarding public access to documents held by the European Parliament, the Council and the Commission, OJ 2001, L 145 p.43.

17 Decision 2005/370, OJ 2005, L 124 p.1.

18 Regulation 1367/2006 on the application of the provisions of the Aarhus Convention to Community institutions and bodies, OJ 2006, L 264 p.13.
} 
that "normally" some commercial information shall be considered confidential ${ }^{19}$ - which means de facto a reversal of the burden of proof. Such a reversal is not compatible with Article 4 (4) in the last subparagraph of the Aarhus Convention.

Finally, the activity of lobbyists at the EU level should be mentioned. In 2017, the EU announced its intention to make the registration of lobbyists compulsory in future. However, their submissions to influence the legislative or administrative process are not systematically disclosed, and the subject matter of their interventions are not even included in a register. Likewise, the names of lobbyists who participate in meetings with Commission officials, and the positions they defend, are all too often kept confidential under the argument of data protection. As yet, the EU is not prepared to state that the very fact that people participate in a meeting with public authorities means that they renounce their right to personal data protection. This would also make an active contribution to the fight against corruption.

With regard to EU Member States legislation, the EU aligned the existing directive that had served as a sort of blueprint for the Aarhus Convention to the final text of the Convention by adopting a new directive..$^{20}$ This Directive was transposed into national legislation by all 28 Member States. The Commission did not take legal action against any Member State for incomplete or incorrect transposition or for badly applying the Directive. ${ }^{21}$

Among other things, the Directive considered "environmental information" to be "emissions, discharges and other releases into the environment" and "the state of human health and safety, including the contamination of the food chain" (Article 2(1b and 1f)), which went beyond the provisions of the Aarhus Convention. It also allowed for information not to be disclosed in order to protect the public interest by maintaining statistical and tax secrecy (Article 4(2d)). When a request was made for information on emissions into the environment, Member States were not allowed to refuse disclosure by invoking the confidentiality of procedures, commercial or industrial information,

\footnotetext{
${ }^{19}$ See for example Regulation 1907/2006 on chemical substances, OJ 2006, L 396 p.1, Article 118; Regulation 1107/2009 on pesticides, OJ 2009, L 309 p.1, Article 63(2); Regulation 528/12 on biocides, OJ 2012, L 167 p.1, Article 66(2).

20 Directive 2003/4 on public access to environmental information, OJ2003, L 41 p.26.

21 This reservation by the Commission might, however, also be due to the fact that Article $\mathrm{x}$ of Directive2003/4 explicitly states that a citizen may apply to a (national) court when his right of access to information is disregarded. The Commission thus leaves it to national courts to deal with such matters.
} 
personal data or files, the interests of a person who voluntarily supplied information or the protection of the environment itself (Article 4(2) second subparagraph).

Spain transposed Directive $2003 / 4$ by legislation in $2006,{ }^{22}$ mostly copying the Directive's provisions. A report in 2016, ${ }^{23}$ indicated that the Ministry of the Environment had received 5,120 requests for information. ${ }^{24}$ At the same time, the Ministry of the Interior had received 46,337 requests for environmental information, the Ministry of Development 22,733, the Ministry of Energy 20,927 and the Meteorology Agency 12,128. Of the Autonomous Communities, Andalucía had had some 40,000 requests, Madrid 17,000, Aragon 16,000, Catalonia 12,000 and the Basque Region 10,000. In contrast, Castilla-la-Mancha reported 462 requests, Castilla-Léon 346, Rioja 302 and 11 regions reported none at all. The authorities mentioned that more than 90 per cent of all requests were answered within a month. No information has been published on the substance of the answers. It is not clear how representative Spain's report is of other EU Member States.

The above-mentioned reports by environmental organizations in Austria, Croatia, Hungary and Czechia, as well as the reports by environmental organizations in Germany give some impression of the overall practical state of compliance with the letter and the spirit of the information provisions of the Aarhus Convention. Generally speaking, authorities at local, regional and national level often start from the assumption that it is better not to share the information they hold with the public and/or with environmental organizations.

The biggest concern in terms of compliance with the Convention by EU Member States is the lack of active dissemination of meaningful information on the state of the environment. The information available on challenges to the environment by economic activities - urban sprawl, infrastructure projects, agriculture and fishing, military activities, transport or energy - and such consequences as soil erosion, desertification, flooding, greenhouse gas emissions, air or water pollution, contaminated sites, invasive alien species, contamination by pesticides, extinction of species (insects,

${ }^{22}$ Law $27 / 2006$ of 18 July which regulates the rights of access to information, public participation and access to justice on environmental matters (it incorporates Directives 2003/4 and 2003/35, BOE no.171 of 19 July 2006, p.27109.

${ }_{23}$ Mapama (Ministry for the Environment), www.mapama.gob.es/es/ministerio/services/informacion/20171116informe2016ley27-2006_tom30434842.pdf (assessed 7 April 2018).

${ }^{24}$ Of these requests, $55 \%$ were made by telephone, $31 \%$ in electronic form, $13 \%$ orally and less than $1 \%$ in writing. 
bees, other animals) are not systematically collected, processed, disseminated or brought to the awareness of the public. As the environment has no voice, it dies away in silence. (Environmental) administrations in practically all Member States do too little to bring the threats to the environment and the possibilities of preventing them to the political discussion table.

Public authorities often do not answer requests for information on the environment, or answer with excessively long delays. The Convention provided that requests should be answered within a month, in exceptional circumstances within two months (Article 4(2)) and Directive 2003/4 repeated that provision (Article 3(2)). However, neither legal instrument provided for sanctions in cases of non-compliance. It could have stated that the lack of a substantive answer is assumed to be a negative answer and that this assumption cannot either be remedied by a subsequent answer; this would at least have allowed for a court to state the failure. Another option would have been to require the administration which does not answer within the provided time-span, to pay a forfeiture amount (for example 100, 300 or 500 euro) to a private charity organization. In the absence of any sanction - also at the level of Member States - the requirement to answer within a specific time-span is pointless. And on top of all of this are the long delays and the cost of court procedures, which act as a deterrent.

The situation in non-EU countries is similar, although the national legislation is not even obliged to follow the EU Directive2003/4. By way of example, reports from Belarus and Georgia for 2017 have been examined. ${ }^{25}$ Both countries argued that the Aarhus Convention is directly applicable. Because they do not have specific national legislation on access to environmental information, they look to general legislation such as the general administrative code, the law on State secrets or an amendment of Article 6 of the Law on the protection of the environment (Georgia), the Environmental Pollution Act 2002 or Law 333-3 from the end of 2015 which amended several pieces of legislation on the Belarus environment (Belarus). Both countries give plenty of information about the measures taken, but not about the results achieved. Neither country gives details about results or failures, but only mentions "some" difficulties

Overall, all Contracting Parties have the legislative instruments available by which they can fully apply the human right of access to environmental information stipulated by

25 See https://www.unece.org/env/pp/reports_trc_implementation_2017.html (assessed 7 April 2018). The reports were chosen, because they were available also in English. 
the Aarhus Convention. Information on administrative practice is limited, and Contracting Parties appear not to be too willing to report on their practice in detail. In the twenty years of its existence, the Aarhus Convention has not fully achieved an "open society" system, in which decisions are taken as openly as possible and as closely as possible to the citizen. Administrative secrecy and economic confidentiality continue to limit transparency and ensure that citizens are regularly and fully informed about the state of their local, regional or national environment and all the measures that intend to amend it. And active dissemination of information on the environment can still be considerably improved, at local, provincial, national and EU level alike. Public authorities still have to put into practice the provision of Recital 17 of the Convention that they hold environmental information not in their own interest, but in the public's.

\section{Public participation in environmental decision-making}

The Aarhus Convention provided for a right of the public concerned to participate in the decision-making on

- permits for activities which were listed in its Annex I (Article 6(1a));

- the deliberate release of genetic organisms into the environment ${ }^{26}$;

- activities which, according to the national law of the Contracting Parties, may have a significant effect on the environment (Article 6(1b));

- plans and programs related to the environment (Article 7).

As regards legislation and regulations, the Convention limited itself to making a recommendation (Article 8). This provision will not further be discussed hereafter.

The Convention provided detailed indications on how to make this right of participation effective, such as timescales, the publication of documents, the rights of the public concerned and use to be made of the information collected. In each particular case, the Contracted Parties have to decide what the "public concerned" is.

In the electronic age, it is more and more common to put a draft - of a permit for a project, a plan or program or even of a report - on a website and invite comments within a specific time-span. However, as it is understood by Article 6 of the Convention, this is a form of consultation, not of participation.

\footnotetext{
${ }^{26}$ Amendment of 2005. Internationally, this amendment has not yet entered into force.
} 
Under Article 6 the public must be informed, in an adequate, timely and effective manner, of the details of the proposed activity. They must dispose of sufficient time to prepare and participate effectively in the decision-making procedure. They must be able to participate "early" in the process, "when all options are open and effective participation can take place". It must be able to ask for information which is "relevant for the decision-making, including the main alternatives which had been studied." And they must have the chance to submit comments, information, analysis or opinion in writing or to a public hearing or enquiry. ${ }^{27}$

The public authorities which set in motion the decision-making process, must inform the public of the expected effects of the activity on the environment, including the residues and emissions that are expected to be generated. Furthermore, they shall make available a description of the measures to mitigate negative effects on the environment. Finally, they must make available a non-technical summary of the documentation concerning the proposed activity. At the end of the participation process, the public authorities shall take due account of the comments received. Once a decision on the activity has been taken, they shall give the reasons for their decisions and for the options they have chosen.

It follows that the participation procedure is far more than a mere consultation procedure. It is a bilateral process which involves continuous communication between the public authorities and the public concerned, whereas the consultation process is "unilateral", in the sense that no communication needs to take place between the public and the authorities: the public's input is limited to comments on the activity as it stands. What the authorities do with the input, is their matter, they are not obliged to explain their final decision. The moment at which they consult the public, in which form, with the help of which documentation and with which delays remain almost entirely their choice.

There is another problem with the participation procedure ${ }^{28}$ It is particularly relevant to cases of internet consultations, but it is not limited to this: the choice of the "public concerned" often neglects whole groups of society, such as children, the elderly, women, immigrants, the disabled, low literacy people, people with language difficulties, ethnic or religious minorities, the economically disadvantaged or people without access

\footnotetext{
27 For details of these entitlements, see Article 6 of the Aarhus Convention.

${ }^{28}$ I am grateful to my colleague Lorenzo Squintani, University of Groningen, for drawing my attention to this problem.
} 
to the internet. Taken together, those groups might well constitute the majority of a given population, so participation in the decision-making of a given project or plan is left to an "acting minority"29. This problem goes far beyond the Aarhus Convention or the environment in general and is linked to the very concept of democracy itself. However, it certainly requires the public authorities to take very careful action if as much of the population as possible is to participate in the process.

As regards projects, the EU authorities do not grant permits, either for projects which are part of the trans-European networks for transport or energy or which receive funding from EU structural funds. ${ }^{30}$ All projects are authorized by national authorities.

For environmental plans and programs which are adopted by EU authorities, Article 9 of Regulation 1367/2006 31 makes provisions on public participation in decisionmaking. The provisions try to reproduce Articles 6 and 7 of the Aarhus Convention. There are, though, a number of significant differences:

Regulation1367/2006 refers to plans or programs which are "required under legislative, regulatory or administrative provisions". This restriction is not found in the Aarhus Convention. ${ }^{32}$ The Regulation also excludes financial plans and programs. Likewise, this is not found in the Aarhus Convention.

The exclusion of emergency plans and plans for civil protection in Regulation $1367 / 2006$, absent from the Aarhus Convention, may be justified because there are plans that intend to prevent damage from floods and other natural or man-made catastrophes. It is not justified where reconstruction measures are planned after a catastrophe.

In practice, EU institutions adopted numerous environment-related plans or programs which are provided for by legislative, regulatory or administrative acts, without trying to ensure appropriate public participation. ${ }^{33}$

\footnotetext{
${ }^{29}$ A term coined by the British historian Arnold Toynbee.

30 See Krämer, L.: "The EU and the participation of civil society in large projects", in: B. Vanheusden L. Squintani (eds): EU environment and planning law. Aspects of large-scale projects. Cambridge a.o. 2016, p.45

31 Regulation 1367/2006 (fn.18, above).

32 In case C-567/10, Inter-Environnement Bruxelles, ECLI:EU:C:2012:159, the CJEU had declared, for a national plan, that a plan or program is also "required", when the regulatory act in question determines the competent authority which is charged to adopt the plan and when it contains provisions concerning the elaboration of the plan. Whether this judgment will be applied by the EU institutions, is not clear.

${ }^{33}$ Examples are annual work programs for industrial standardization, a work plan for the eco-design of energy related products, an EU strategy on the adaptation to climate change, a forest strategy, a biodiversity strategy, a blueprint for water resources, a plan on sustainable production and consumption
} 
When the EU Commission provides for participation, it posts the respective text on the internet and asks for comments which are to be submitted within a period of eight weeks. These texts are posted in English, and occasionally also in German and French, though the EU has 24 official languages. Both the European Ombudsman ${ }^{34}$ and the European Parliament ${ }^{35}$ considered this practice to be discriminating, although no changes were made.

The consultation procedure by the Commission is not done "as early as possible" when all options are open. As mentioned, the Commission publishes the different options for legislation, administrative acts, plans or programs, etc. - only after it has formally adopted its proposal, whereas a participation procedure does precisely the opposite: the general public provide their input and participate, according to the Aarhus Convention, before the authorities put forward a specific option

In practice the whole participation procedure at EU level is more like a consultation procedure in response to the expressed intention of the EU Commission not to grant (participation) rights to citizens. ${ }^{36}$ It is not in compliance with the Aarhus Convention.

As regards participation procedures in EU Member States, the EU adopted a directive on the assessment of the environmental impact of certain public and private projects which provided for the participation of the public concerned. ${ }^{37}$ The projects which come under this Directive are almost entirely to the same as those listed in annex I to the Aarhus Convention. Another directive provided for the participation of the public in the permit procedure for larger industrial installations listed in an annex. ${ }^{38}$ For other industrial installations, no participation procedure is envisaged, in particular not for medium combustion plants, for which the EU adopted legislation in $2015 .{ }^{39}$

or a strategy on the conservation of the marine world. For details, see Krämer, L.: "The EU and public participation in decision-making", in: J:Jendroska - M.Bar (eds): Procedural environmental rights: Principle $X$ in theory and practice, Cambridge a.o. 2018, p.121.

${ }^{34}$ European Ombudsman, Decision of 4 December 2012 (640/2012/A).

${ }^{35}$ European Parliament, Resolution of 14 June 2012 (2012/2676/RSP), P7_TA(2012) 256.

36 See Commission, COM (2002) 704 p.10:"A situation should be avoided in which a Commission proposal could be challenged in court on the grounds of alleged lack of consultation of interested parties. Such an over-legalistic approach would be incompatible with the need for timely delivery of policy, and with the expectation of the citizens that the European institutions should deliver on substance rather than concentrating on procedures." It is true, though, that this argument would be valid for any local, provincial, regional or national administration.

37 Directive 2011/92, OJ 2012, L 26, p.1. Article 2(1)(g) of that Directive calls the process "consultation", while Articles 6(2) and 11(1) refer to it as "participation".

38 Directive 2010/75 on industrial emissions, OJ2010, L xxx

39 Directive 2015/2193 on medium combustion plants, OJ 2015, L313 p.1. 
Member States largely transposed the various directives into their national legislation, so at least the formal transposition of the participation provisions is ensured. France adopted detailed provisions concerning public participation in decisions regarding projects, plans or programs, ${ }^{40}$ but apart from that no other Member States appears to have adopted specific provisions to make public participation effective. ${ }^{41}$

A problem with the procedure for assessing environmental impact is that the developer of a project may ask for a so-called "scoping" meeting with the authorizing administration. ${ }^{42}$ In such meetings, the kind of information which the developer produces and the details, together with his/her request for authorization, is fixed. It is this information which is subsequently submitted to the public concerned. However, the public concerned cannot participate in the scoping meetings.

When a project is likely to have an impact on another EU Member State, Article 7 of Directive 2011/92 provides that intergovernmental consultation shall take place; this consultation of the neighboring government substitutes public participation in the neighboring country which is or may be affected by the project. Similar provisions apply when the granting of a permit for a large industrial installation under Directive 2010/75 is being questioned.

Limiting this procedure to other EU Member States, but not to third countries, is not compatible with the Aarhus Convention, which prohibits any discrimination on grounds of nationality or domicile (Article 3(9)). And substituting the individual right to participate in decision-making with an intergovernmental procedure is not compatible with the Aarhus Convention either. The Convention does not allow such substitution.

Projects that come under the system of the Trans-European Networks (TEN) have a specific problem. ${ }^{43}$ These networks provide for the realization of transport, energy and telecommunication projects which are of common European interest. Specific regulations for energy ${ }^{44}$ and transport ${ }^{45}$ projects give the details of planning and constructing such projects. Energy projects are pre-selected by various regional committees, in which affected Member States and professional bodies, but no

\footnotetext{
40 France, Code de l'environnement, Articles 121 to 123.

41 See for some of the problems in Spain Bolano Pineiro, M. and Lasagabaster Herriarte, I.: "Public participation in rule-making and Decision-Making in environmental matters - legal framework and jurisprudence in Spain", In: J.Jendroska - M.Bar (fn.33, above), p.143.

42 Directive 2011/92 (fn xxx, above), Article 5(2).

43 See Articles 172 to 174 TFEU.

44 Regulation 347/2013, OJ 2013, L 115, p.39.

45 Regulation 1315/2013, OJ 2013, L 348, p.1.
} 
environmental organizations, are represented. The different regional proposals are taken up by a Commission regulation ${ }^{46}$ which limits itself by indicating in a Recital that environmental representatives have been consulted. The transport projects of EU interest are specified in Regulation 1315/2013 itself; no information is given on the participation of the concerned public. Listed energy and transport projects then have to undergo an environmental impact assessment which is split up according to the national frontiers, as there is no EU environmental impact assessment procedure.

The problem of public participation in decision-making in large projects, which often involve several Member States, needs to be reconsidered. When a project is put on an EU list, it automatically acquires the greatest national priority status, funding and other support. The subsequent environmental impact assessment, in which the public participates, can, at best, relocate the project by a few meters or make other minor corrections, but it cannot question the project as a whole. This inevitably leads to concerns, frustrations and resistance from the affected public. The examples of Stuttgart railway station - which was part of a TEN railway project between Paris and Bratislava - or the high-speed train between Lyon and Turin, are examples of the societal problems which such planning may cause if there is no adequate citizen participation. ${ }^{47}$

It was mentioned above that the solution to the transparency problem in environmental matters probably lies in the public authorities more actively disseminating environmental information. Likewise, making public participation in environmental decision-making really effective - a key element in a democratic society -, requires the public authorities to be much more active. The environment is in the general interest but it does not have a voice. It is not backed by powerful people with vested interests, who have sufficient human and financial resources to monitor the evolution of the state of the environment in all its facets - air and water, soil and products, waste, climate, nature etc. - defend the environment and actively promote its interests, just as producers or farmers and their associations, representatives, chambers and other semi-official bodies defend and promote their interests. Public authorities, therefore,

\footnotetext{
46 Commission Regulation 1391/2013, OJ 2013, L 349, p.28.

47 The problem is not limited to transboundary projects: the objections to high-speed trains in Flanders or in the South of France, the local resistance to freight trains in the Rhine Valley (Germany) or the problems with the high-speed train between Lyon and Turin on the Italian side are examples of problems in Member States. Also in Germany, the North-South electricity lines had to be placed underground, at a cost of some 15 billion euro, at the insistence of the local population.
} 
have to take up this task, set up environmental agencies or similar bodies, organize participation, pay for studies and research and let environmental interests prevail over competing economic interests. This is a sort of direct democracy, in which most of the Contracting Parties to the Aarhus Convention may learn from Switzerland's referendum approach or the above-mentioned French approach.

Even more important than the public's right to participate in decision-making is their right to participate in drawing up plans and programs, because of the horizontal nature of such plans and because of their long-term validity. The EU adopted a directive on this sort of participation, but it covered only six specific plans. ${ }^{48}$ The original concept was to include other plans or programs in the Directive at a later stage but this never happened. The Directive was transposed into national legislation, though the participation procedure was all too often substituted by a mere consultation. Monitoring of its practical application has not been systematic.

Apart from the six types of plan referred to in Directive 2003/35, environment-related plans or programs, which form the basis for the requirement of an environmental impact assessment of specific projects, must ensure public participation. ${ }^{49}$ These plans and programs are not covered by Directive 2003/35. Also excluded are plans or programs under the water framework Directive 2000/60, although public participation is insufficiently regulated. ${ }^{50}$

The non-EU Parties to the Convention are essentially in the same situation with regard to participating in project decisions as EU Member States: legislation more or less completely transposes the provisions of the Convention into the national legal order and often provides for consultation rather than participation. However, application in practice by no means follows the letter or the spirit of the Convention. "We have observed the substantial gap between law in the books and law in action."51 This observation is applicable to practically all non-EU Parties and most EU Parties. Noncompliance occurs in all aspects of participation (for example, delays in early

48 Directive 2003/35 providing for public participation in plans and programs, OJ 2003, L 156 p.17. The plans covered concern waste, packaging waste, batteries, nitrates in water and air quality plans see Annex I to Directive 2003/35.

${ }^{49}$ Directive 2001/42 on the assessment of the effects of certain plans and programs on the environment, OJ 2001, L 197 p.30.

50 Directive 2000/60, OJ 2000, L 327 p.1, Article 14. That Article provides for consultation only.

51 NGO report on Bosnia-Herzegovina 2017, p.34; https://www.unece.org/env/pp/reports_organisations_2017.html. A comparison between the official Governmental report and the NGO-report for any Contracting Party give an impressive illustration of the difference between the wording of texts and the application in practice. 
information, ${ }^{52}$ the communication of information, the minutes of hearings, the consideration of comments made, explaining the final decision, etc. $)^{53}$

A good but depressing impression of public participation in environmental decisionmaking can be obtained by the communications (complaints) submitted and/or decided by the Aarhus Convention Compliance Committee. Of the 109 communications which were submitted and/or decided before the end of $2017,{ }^{54}$ two-thirds (69) dealt with the legislation and practice of participation. Even though these communications are just the tip of the iceberg, they clearly show how far removed the administrative practice in most countries is from the letter and spirit of the Aarhus Convention's provisions on the right of public participation. All too often the attitude of public authorities seems to consist of ignoring the public's right to participate and forgetting that respecting this right requires an active effort on their part.

It is true that environmental organizations in practically all Contracting Parties to the Aarhus Convention are short of human and financial resources, have trouble in organizing themselves and have to fight against the attitude that citizens only take an interest in planning - whether a project or a plan - when they are directly affected. This attitude is often coupled with the public's "NIMBY-attitude", which means that they are happy for the project (plan) to go ahead, but "Not In My Backyard". As most countries inside and outside the EU have adopted measures to make the life of ad-hoc public initiatives difficult, public participation can be improved in all countries of the Aarhus Convention.

Very few States have made the effort to actively improve public participation. Public authorities have not yet accepted the Convention's message that public participation in environmental decision-making is part of the democratic system because the environment is not the property of the public authorities. Instead they adhere to the idea that if the public does not participate, it might be better for the final decision on projects or plans because the authorities know best and understand what is good or not so good for the environment.

\footnotetext{
52 The NGO-report for Kazakhstan (fn.51, above) reports that information on a project is disclosed twenty days before the public hearing on the project.

53 The NGO-report on Belarus (fn.51, above) lists on p.13 the most frequent cases of non-compliance with the provisions of the Aarhus Convention.

54 Of the 157 communications which were on the UNECE list (https://www.unece.org/env/pp/cc/com.html, assessed on 19 April 2018), 48 were removed because the Compliance Committee considered them to be inadmissible or closed with no conclusions.
} 


\section{Access to environmental justice}

It is extremely difficult to access EU courts on environmental matters. When an EU measure is addressed to a specific person, that person may tackle it in court; however, in environmental matters, decisions by an EU institution or body are rarely addressed to a specific person, as they concern the environment which is of general interest. In those cases in which they are not addressees, if people or environmental associations wish to gain access to the EU Court of Justice (CJEU) they must be directly and individually concerned with the measure; in certain cases, it is sufficient to be individually concerned. ${ }^{55}$ This obstacle, which is considerable in the rather restrictive jurisdiction of the CJEU, ${ }^{56}$ is so great that so far no action introduced by an NGO to the CJEU has ever been declared admissible. The Aarhus Convention Compliance Committee found the practice of the EU courts incompatible with the provisions of the Aarhus Convention. ${ }^{57}$

The CJEU asked national courts to interpret national procedural provisions to the fullest extent possible so that environmental protection organizations could challenge measures liable to be contrary to EU environmental law in court. ${ }^{58}$ However, the CJEU itself is not prepared to interpret Article 263 TFEU to the fullest extent possible.

The EU Commission tried to introduce a directive on access to environmental justice, but did not obtain the EU Council's agreement. ${ }^{59}$ EU Member State legislation on access to justice was thus dependent on national evolution. In some Member States,

\footnotetext{
55 For details, see Article 263(4) TFEU).

56 For "individual concern", the CJEU applies the so-called Plaumann-formula which it developed in case 25/62, Plaumann v. Commission, ECLI:EU:C:1963:17: "Persons other than those to whom a decision is addressed may only claim to be individually concerned if that decision affects them by reason of certain attributes which are peculiar to them or by reason of circumstances in which they are differentiated from all other persons and by virtue of those factors distinguishes them individually just as in the case of the person addressed".

In order for a person to be directly concerned, "the measure must directly affect the legal situation of that individual and there must be no discretion left to the addressees of that measure who are responsible for its implementation, that implementation being purely automatic and resulting from the EU rules alone, without the application of other intermediaries", General Court, case T-18/10 Inuit Tapiriit Kanatami, ECLI:EU:T:2011:419.

57 Aarhus Convention Compliance Committee, ACCC/C/2008/32 part I and part II. These findings still require approval by the next meeting of the Parties in 2021.

58 CJEU, case C-240/09 Lesoochranárske zoskupenie,ECLI:EU:C:2011:125, paragraphs 49 et seq.: "it is inconceivable that Article 9(3) of the Aarhus Convention be interpreted in such a way as to make it in practice impossible or excessively difficult to exercise rights conferred by EU law... it is for the [national court] to interpret, to the fullest extent possible, the procedural rules... so as to enable an environmental protection organization to challenge before a court decisions taken following administrative proceedings liable to be contrary to EU environmental law."

59 Commission, COM (2003) 624; withdrawal in 2014.
} 
national laws were reformed, ${ }^{60}$ but the traditional procedural and substantive structures on access to environmental justice remained. In several countries, the courts undertook to facilitate access to courts in environmental matters, in particular after the CJEU's above-mentioned judgment of 2011.61

The situation in non-EU countries is rather similar. There has been some evolution in the legislation and jurisprudence on access to justice, but the procedures and the substance of the traditional ways to accede to justice have not significantly changed. Of the 109 communications to the Aarhus Convention Compliance Committee, 35 invoked infringements of Article 9 of the Convention, some of which also invoked infringements of other provisions. The facts described in the communications give the impression - for EU and non-EU countries alike - that the adoption and ratification of the Aarhus Convention has not made access to environmental justice much easier.

\section{A balance}

Although the Aarhus Convention is open to non-European countries, it has yet to be adhered to by a third country. However, the Convention has had some influence beyond its geographical field of application. Attempts to negotiate a global agreement on the three pillars of the Aarhus Convention failed because of resistance by the United States and Saudi Arabia. In 2010, UNEP adopted "Guidelines for the development of national legislation on access to information, public participation and access to justice in environmental matters.". And in March 2018, a regional agreement on access to information, public participation and justice in environmental matters in Latin America and the Caribbean was adopted in Escasú (Costa Rica), under the auspices of the Economic Commission for Latin America and the Caribbean. ${ }^{62}$

The greatest merit of the Aarhus Convention is that it exists. Never before have environmental rights for citizens and environmental organizations been so clearly expressed in a legally binding text. It is the first international agreement that gives rights to civil society so that the quality of the environment can be preserved, protected and

${ }^{60}$ Examples are Spain, Portugal, France, Germany and the United Kingdom (costs of procedure)

61 Examples are Latvia, Germany, Austria and the United Kingdom. As regards Latvia see Mikosa, Z.: "Implementation of the Aarhus Convention through actio popularis: Article 9(3) of the Aarhus Convention and actio popularis", in J.Jendroskska- M.Bar (fn.33, above), p.261.

62 See comments on the draft instrument by Zuluaga, J.: "Definitions of the Aarhus Convention v. the proposal for a new Latin America and the Caribbean instrument - mapping the differences in the material scope of procedural environmental rights in international law", in: J.Jendroska- M.Bar (fn.33, above), p.39. 
improved. And it goes even further: UNECE rightly praises the Convention because it also deals with "government accountability, transparency and responsiveness."63

Also innovative is the fact that the Compliance Committee deals with communications from the public and environmental organizations about the application of the Convention's provisions in the countries that ratified the Convention. The para-judicial nature of the Committee's findings and the high quality of its assessments make the practical application of the Convention unique in international law. The Committee's findings are widely respected and have led to a considerable number of amendments in legislative texts and in the jurisprudence of the contracting Parties to the Convention.

The various pillars of the Convention have been unequally successful. Access to environmental information is, by far, the part of the Convention which has led to most changes in national (and the EU) administrations, although it is clear that any changes in this area take time. Public authorities will take a long time to admit that they hold information on the environment in the public and not in their own interest and change their general approach correspondingly. Throughout the geographical area in which the Convention is applied, the public authorities still consider that they know what is best for the environment, and all too often they side with economic interests. Information is easily withheld in the name of data protection - often abused and transformed into a sort of "polluters' protection" - and ongoing decision-making processes which prevent disclosure and justify maintaining administrative secrecy.

In particular, the active dissemination of information on the environment can be considerably improved. Transparency is the most effective way of getting citizens to be more interested and involved in protecting the planet which is the only one we have. Public authorities do not do enough to inform citizens on the planetary threats to the environment - climate change, loss of biodiversity, the omnipresence of chemicals, badly managed resources, poverty - and to suggest how individuals can help to improve the state of affairs.

The Convention does not provide for sanctions for those authorities that react to applications for access to information after a considerable delay or not at all or which do not disseminate important information on the state of the environment. This lack is often taken advantage of by authorities not to respond to applications on time. Very few countries have an effective system of administrative or criminal sanctions against

63 UNECE, https://www.unece.org/env/pp/introduction.html (assessed 17 April 2018). 
public authorities that do not comply with their legal obligation to respond to applications in time or to actively disseminate information on the environment. In this last respect, the Convention is formulated in too general a way. ${ }^{64}$

Overall, public participation in environmental decision-making under the Aarhus Convention is by no means a success story. Significant improvements in the participation process are rare and all too often political or administrative decisions about projects, plans or programs are taken before the public are consulted or given a chance to participate. This particularly affects large projects, such as the construction of high-speed railways, motorways, ports and airports, gas pipelines, electricity lines, trans-European projects etc. In many instances, public participation is little more than a fig leaf that justifies a project. Public authorities do not normally make any special effort to get citizens to participate in the decision-making process when all options are still open and citizens all too often adopt a NIMBY-attitude to projects. The Aarhus Convention has done little to change this general situation.

The term "plans and programs related to the environment" in Article 7 of the Convention, which provides for public participation, is very broad. Numerous plans or programs in the transport, industry, energy and agricultural sectors are considered by public authorities not to be environment-related, so the public participation provisions of the Convention need not be respected. Another important problem is how noncompliance with the participation provisions for plans and programs can be sanctioned. The Aarhus Convention does not state that plans or programs without public participation are void and national law provides no system of sanctions either. It would be highly desirable for EU legislation on the environmental impact assessment of plans and programs ${ }^{65}$ to provide for the judicial review of cases in which public participation is alleged not to have taken place. Directive2003/35 on plans and programs should also incorporate such a provision. Furthermore, the planning of trans-European networks and the execution of individual projects under these plans need binding provisions on public participation which can be enforced by court action.

\footnotetext{
64 A noteworthy example is the publication of a report on the state of the environment: the Convention provides that such a report be published every "three or four years" (Article5(4)). Nevertheless, Article 2 of Regulation 1210/90 (OJ 1990, L 120p.1)) provides that the EU publish a report on the state of the environment every five years. This provision has not been amended by the new Regulation 401/2009, OJ 2009, L 126 p.13, Article2(h).

${ }^{65}$ Directive 2001/42 (fn.49, above)
} 
As can be seen by these brief remarks, public participation in environment-related decision-making needs to be improved and extended beyond the provisions of the Aarhus Convention. There should be no false hope, though: any significant attempt at reform will meet the determined resistance of the public authorities themselves which see increased and intensified public participation more as a threat to their own planning privileges than as progress towards environmental democracy. Hence, the provisions on public participation may not have significantly improved by the time the Aarhus Convention celebrates its 40th anniversary.

The Aarhus Convention has not led to innovative improvements in terms of access to environmental justice, either. The concept of access to justice is clearly laid down in Article 9(3) of the Convention: civil society should have the chance to challenge in court $^{66}$ those actions and omissions by private persons and public authorities that contravene existing provisions on the protection of the environment. This concept was based on the reality that in all the countries of the Aarhus Convention, the protection of the environment is the responsibility of the public authorities. However, little or nothing is said about the consequences of the public authorities not fulfilling their responsibility, their granting permits to pollute, the authorization of environmentally harmful infrastructure projects or not intervening when harmful products are marketed or polluting substances are emitted. In these cases, according to the Convention, civil society should be able to defend the environment by challenging the acts or omissions by polluters or by public authorities in court.

The Convention provides that the Contracting Parties should decide the conditions under which members of the public can enjoy the possibility of initiating judicial review under Article 9(3). This was understood by most Contracting Parties to mean that they could implement Article9 (3) at their discretion and that they were not obliged to initiate legislation in order to implement it. Only very little, limited legislation was adopted. The CJEU tried to mobilize national courts to give the broadest possible interpretation to national rules on access to environmental justice. However, this only has limited effects, as courts also have to apply the national rules on access.

The barriers preventing individual citizens and environmental organizations from suing private polluters in court continue to be high. They include the vague formulation of

\footnotetext{
${ }^{66}$ It is true that Article 9(3) of the Convention does not mention judicial procedures alone, but refers to "administrative or judicial procedures". However, it follows from Article 9(4) of the Convention that Article 9(3) has judicial reviews in mind, as injunctive relief is granted by courts, not by administrations.
} 
environmental legislation, the costs and length of procedures, different standing rules, the conservative application of laws by judges, the need to resort to legal professionals (solicitors, barristers, attorneys, etc.). Judges fear an enormous number of procedures if the letter and spirit of Article 9(3) were fully applied, and although empirical research has long discounted that this would be the case,${ }^{67}$ the fear remains. In practice, then, the public authorities continue to have the monopoly on protecting the environment and dealing with private polluters.

So, on its 20th anniversary, the Aarhus Convention is a little like the shadows in Plato's allegory of the cave. In theory it is a great legal instrument for introducing environmental democracy and allowing citizens to protect the environment: all reasonable people probably agree with the theoretical concept of environmental democracy, full transparency and public authorities holding environmental information in the interest of the citizens. It is both desirable and necessary that the general public participate in the environmental decisions that need to be taken for projects, plans and programs, and, if possible, this participation should even extend to "executive regulations and other generally applicable legally binding rules" (Article 8 of the Convention). Likewise, the public should have ready access to the courts if existing provisions on the protection of the environment are disregarded, particularly in those cases in which the public authorities, for one reason or another, do not themselves initiate court action.

When the Platonic ideas become true in the real world they become something different, and the three pillars of the Convention do not constitute an exception: there is probably more transparency in the world on environmental matters than twenty years ago. This is good progress, but it is not worth examining in detail whether this has been achieved by technological development (internet, electronic means of communication etc.), the greater visibility of the planetary problems of climate change and demographic development, or the younger generation's more limited acceptance of administrative secrecy.

In contrast, the two pillars on public participation and access to environmental justice show rather limited progress. Public authorities and courts have successfully fought against the full implementation of these two concepts and have only reluctantly

67 See for example, Sadeleer, N. de, Roller, G., M.Dross, M.(eds): Access to justice in environmental matters and the role of NGOs, empirical findings and legal appraisal. Groningen 2005; Jans, J., Macrory, R., Moreno Molina, A. M. (eds): National courts and EU environmental law. Groningen 2013. 
conceded to increased participation and improved access to justice. The vast majority of citizens do not perceive the environment to be a common, shared interest, and only feel concerned when their own interests are being affected. Citizens do not feel that climate change, loss of biodiversity, soil erosion or the quantity and quality water normally affect their interests. Environmental NGOs do not fill this gap, as they lack resources, have less bargaining power than vested interests and are unable to make people aware that the protection of the environment is a general interest that needs the support and protection of everybody.

The idea of "business as usual" largely succeeded in bringing the extraordinary Aarhus Convention into the daily administrative and judicial routine. It can only be hoped that the celebration of the 40th anniversary of the Convention will report better results.

\section{BIBLIOGRAPHY:}

Andrusevich, A., Kern, S: Case law of the Aarhus Convention Compliance Committee 2004-2014. 3rd ed. Lviv 2016.

Bolano Pineiro, M. and Lasagabaster Herriarte, I.: "Public participation in rule-making and Decision-Making in environmental matters - legal framework and jurisprudence in Spain", in: J:Jendroska - M.Bar (eds): Procedural environmental rights: Principle X in theory and practice, Cambridge a.o. 2018, p.143

Ebbesson, J., Gaugitsch, H., Jendroska, J., Stec, S. Marshall, F.: The Aarhus Convention. An implementation guide. 2nd ed. Geneva 2014.

Jans, J., Macrory, R., Moreno Molina, A. M. (eds): National courts and EU environmental law. Groningen 2013.

Krämer, L.: "The EU and the participation of civil society in large projects", in: B.Vanheusden - L.Squintani (eds): EU environment and planning law. Aspects of large-scale projects. Cambridge a.o. 2016, p.45. 
Krämer, L.: "The EU and public participation in decision-making", in: J:Jendroska M.Bar (eds): Procedural environmental rights: Principle $X$ in theory and practice, Cambridge a.o. 2018, p.121

Mikosa, Z.: "Implementation of the Aarhus Convention through actio popularis: Article 9(3) of the Aarhus Convention and actio popularis", in: J:Jendroska - M.Bar (eds): Procedural environmental rights: Principle $X$ in theory and practice, Cambridge a.o. 2018, p.261.

Sadeleer, N. de, Roller, G., M.Dross, M.(eds): Access to justice in environmental matters and the role of NGOs, empirical findings and legal appraisal. Groningen 2005

Zuluaga, J.: "Definitions of the Aarhus Convention v. the proposal for a new Latin America and the Caribbean instrument - mapping the differences in the material scope of procedural environmental rights in international law", in: J.Jendroska- M.Bar (fn.33, above), p.39. 